\title{
Human Resource Capacity Needs at the District Assemblies: A Study at Assin South District Assembly in Ghana
}

\author{
Daniel Odoom ${ }^{1}$, Christian Kyeremeh ${ }^{2}$ \& Ernest Opoku ${ }^{1}$ \\ ${ }^{1}$ Institute for Development Studies, University of Cape Coast, Ghana \\ ${ }^{2}$ School of Business and Management Studies, Sunyani Polytechnic, Ghana \\ Correspondence: Christian Kyeremeh, School of Business and Management Studies, Sunyani Polytechnic, \\ Ghana. E-mail: kriskopap@gmail.com
}

\author{
Received: August 19, 2014 Accepted: August 23, $2014 \quad$ Online Published: September 24, 2014 \\ doi: $10.5539 /$ jsd.v7n5p 177 \\ URL: http://dx.doi.org/10.5539/jsd.v7n5p177
}

\begin{abstract}
The study examined the human resource (HR) capacity needs at the Assin South District Assembly using the descriptive and non-interventional research design. Purposive and quota sampling techniques were used to select 53 respondents with interview schedule and interview guide as the research instruments. The study revealed that the existing institutional arrangements in Ghana's decentralized government system did not allow the Assembly to properly address its HR capacity needs. Besides, poor staff attraction, low remuneration, poor accommodation facilities and inadequate training and development contributed to the Assembly's HR capacity needs. The study recommended that the government should decentralize the HR arrangements at the DAs to grant autonomy to the Personnel Management Department at the Assembly to actively address its own HR capacity needs. The government must effectively collaborate with the Assembly to provide adequate logistics, attractive incentives and social amenities so as to attract well-qualified personnel for smooth decentralization.
\end{abstract}

Keywords: decentralization, subsidiarity principle, human resource capacity, development

\section{Introduction}

As a concept, decentralization is premised on the conviction that there will be a correlation between governance and citizens' wellbeing only if there is a transfer of functions and powers, skills and competencies and means and resources to the lowest levels of governance (Ahwoi, 2006; Gyabaah, 2006). Decentralization helps to improve good local governance and delivery of effective public service by increasing 'allocative' and 'productive' efficiency. But this significant assumption depends on its design, the institutional, fiscal and human resource (HR) development capacity arrangements governing its strategic implementation (World Bank, 2003). The systems theory identifies HR as the most vital factor for organizational success (Bastedo, 2004). In essence, effective decentralized system, from systems theory standpoint, requires improved HR capacities at the various levels of government administration (Antwi \& Analoui, 2008).

According to World Bank (2000), the decentralized system of government in Ghana was given legal backing by the Local Government Law 1988, Provisional National Defense Council Law (PNDCL) 207 and amended in Chapter 20 of the 1992 Constitution, Local Government Act, 1993, Act 462 as a consequential outcome of reforming the country's public sector. To ensure the effectiveness of the policy, the Ministry of Local Government and Rural Development (MLGRD) embarked on a District Resourcing Program in 1992 under the ministry's three-year Rolling Public Investment Program (PIP) aimed at providing accommodation and other logistics to the 45 newly created districts in the year 1988. The Institute of Local Government Studies (ILGS) was also mandated to play its role in the development of HR to ensure proper decentralization. In order to strengthen the HR capacity at the DAs, budget and planning officers were posted by the Ministry of Finance (MF) and the National Development Planning Commission (NDPC) to some of the districts (Ahwoi, 2006).

However, most DAs were faced with inadequate HR capacities. Kyeremeh (1996) agrees with Ayee (1996) that most of the DAs did not have enough qualified personnel to which inhibited the effectiveness of the country's decentralization policy (World Bank, 1996). The inability of the previous structure to achieve effective local government (LG) system led to further alterations in 1996, 2002, 2004, 2007, and in 2012 which brought into existence the current LG structure. This was done to promote effective grassroots participation in the LG 
administration in terms of planning, implementation, monitoring and evaluation for the delivery of services which enhance the lives of the people of Ghana (Government of Ghana [GoG], 2010). The current system of decentralization has come with additional responsibilities and so takes cognizance of various international and national commitments from donor agencies including the World Bank towards the management of development processes (GoG, 2010). Despite the alterations, most DAs do not have the requisite HR capacity to ensure smooth decentralization (Ahwoi, 2010).

In their attempt to envisage the future of Ghana's decentralization policy, Hoffman and Metzroth (2010) agree with Ndegwa and Levy (2003) that the alteration in the country's decentralization ought to be accompanied by the requisite HR capacities. Ndegwa and Levy (2003) add that in devolving responsibilities to the local level, central governments must consider the technical and managerial ability of DAs to ensure viable decentralization. To understand the HR situation at the DAs requires an appreciation of the HR capacity needs in both the rural and urban centers of the country and the peculiar characteristics of the different DAs (Hoffman \& Metzroth, 2010; Ministry of Local Government and Rural Development [MLGRD], 2007).

\section{Statement of the Problem}

For decentralization to be effective in meeting the growing needs of the citizens there is the need for germane HR capacity. However, most DAs do not have the needed HR capacities to ensure the effective decentralization. Koranteng (2006) contends that the issue of inadequate HR capacities at the DAs is as a result of institutional failure. Koranteng (2006) believes that the existing institutional arrangements on HR capacity at the DAs have failed to properly address the HR challenges at the DAs. The apparent difficulty in this position is that given the control that the government has over its own institutions one would expect that the issue of institutional arrangements which contribute to the problem of inadequate HR capacities at the DAs could have been dealt with for the problem to be solved. But this has not been the case over the years. Contrary to the views of Koranteng (2006), Ahwoi (2010) and Water Aid Ghana (2009) contend that factors such as poor image and poor staff satisfaction are largely responsible for the problematic HR capacities at the DAs. These views have also been supported by Hoffman and Metzroth (2010). Hoffman and Metzroth (2010) add that the issue of poor social amenities, especially in the rural areas compounds the situation. The question that ought to engage the attention of researchers is "What really are the causes of the HR capacity needs at the DAs?" In appreciating this, the MLGRD (2007) and Water Aid Ghana (2009) propose a case-by-case study of the issues across the various DAs. This, it is believed, will help bring to the fore a clearer picture of how the situation prevails especially in the rural and urban areas of the country.

The type of HR capacities that are available for the smooth functioning of Assin South District Assembly's (ASDA) has been a problem. For instance, the Central Regional Coordinating Council (CRCC) (2009) states that as a relatively new DA, the suitability of ASDA's staff strength and their capabilities have been problematic since its establishment. Some efforts made in respect of addressing the current situation such as putting in applications at the OHCS and MLGRD for more qualified staff have not yielded any fruits (ASDA, 2012). The situation is not peculiar to the ASDA. However, this study examined the HR capacity needs at the DAs by using ASDA as a case in order to better appreciate how the problem manifests itself in the rural areas of Ghana so as to proffer measures for improvement. Specifically, the study sought to ascertain the views of workers of the Assembly on the institutional arrangements at the DAs in respect of the Assembly's HR capacity; determined the Assembly's personnel capacity needs; and examined the factors that influence the Assembly's HR capacity needs.

\section{Literature Review}

\subsection{Decentralization in Perspective}

The term 'decentralization' has been subjected to several definitions as it is used differently by different professions, groups and disciplines to suit their own circumstances. Ribot (2002) agrees with Smith (1985) that decentralization is any act by which central government formally cedes powers to actors and institutions at lower levels in a political, administrative and territorial hierarchy. Crook and Sverrison (2001) maintain that successful decentralization lies in centre-local ability of the central government to ensure that substantial resources allocated to local authorities are used in a responsible manner. It also requires respect for local autonomy, and establishment of accountability mechanism through enhanced participation. The rest is allocation of substantial amounts of financial resources (Crook \& Sverrison, 2001). These views have also been supported by Jutting, Kauffmann, McDonnel, Osterrieder, Pinaud and Wegner (2004). Jutting, et al. however, bemoan that strong donor support does not guarantee the success of decentralization in terms of poverty eradication. Manor (2011) agrees with Ahwoi (2010) that substantial resources (including human) to the DAs as well as horizontal and 
downward accountability mechanisms are fundamental requirements to the success of decentralization. All these key elements must be provided in the system; otherwise, if one is missing or is weak the decentralized system will fail (Manor, 2011). In effect, effective decentralization requires better policies and programs designed to empower local governance structures with appropriate autonomy to bring public administration closer to the people and also to ensure proper accountability to the citizenry.

\subsection{Factors That Influence the HR Capacities at the District Assemblies}

Motivation and satisfaction constitute the physical, psychosocial and economic factors of work. Thus, the HR capacities at the DAs are influenced by economic, physical, psychosocial and skill related other factors. If these factors are lacking then the HR capacities of the DAs are likely to be affected adversely (Wood, 2000; World Bank, 2005). The physical component of the determinants includes the physical work environment such as ventilation, tables and chairs for the office, housing for the workers, and workload (Noe, 2005). The economic factors may include the level of pay and benefits, options for career mobility, and degree to which merit is recognized or unsatisfactory performance penalized. This view has also been supported by Donahue, Selden and Ingraham (2000) and Steffensen, Tidemand and Ssewankambo (2004). Donahue, Selden and Ingraham (2000) explain further that effective motivation at the DA level typically rests on the use of appropriate monetary and nonmonetary rewards and incentives, better performance appraisal system, and sound mechanisms that facilitate employee feedback. When better remunerations are available for staff, retention rates become high leading to quality HR capacities at the DAs (Antwi, Cusworth \& Anaolui, 2007).

There are also psychosocial factors that influence employee retention. In every social set up, like an institution, there are role expectations. It is this role expectation which helps members to predict the behavior of one another. Thus any disruption to the system of role expectation may result in disintegration of the entire organization (Antwi \& Analoui, 2008). Workers and administrators can be viewed as members of the same system. In their administrative interaction, when discrepancy arises between what the staff expect the administrators to do and what he/she actually does, the workers will be confronted with the issue of finding a basis for predicting the behavior of the administrator (Schuler \& Jackson, 1995; Steffensen et al., 2004). In his attempt to appreciate the relevance of job satisfaction in organizations, Mullins (2007) argues that workers who perceive the behavior of an administrator as being in consonance with their expectations would want to be satisfied with the work situation. Contrarily, workers whose expectations are not consistent with that of an administrator would more likely be dissatisfied with their job, hence their capacities to willingly work towards organizational goal attainment (Noe, 2005). Similarly, job satisfaction has been found to be a crucial factor in the HR capacities of the DAs. Where satisfaction is high, workers tend to work hard for the growth of the DAs (Antwi \& Analoui, 2008).

\section{Methodology}

\subsection{Study Area}

The Assin South District is located in Central Region of Ghana. The district covers a total land area of 1187 square kilometers representing $12 \%$ of the total land area of the Central Region. The population of the district is 104244 comprising 50936 males and 53308 females. The Assin South District Assembly is the highest political and administrative authority in the district with the mandate to initiate and coordinate all development efforts and to implement policies aimed at sustainable development. The Assembly has a workforce of 57 spread across different departments.

\subsection{Study Design and Data}

The descriptive survey design was adopted for the study. The population of the study consisted of the District Coordinating Director (DCD), District Deputy Coordinating Directors (DDCDs), Sectional Heads and the other members of the Central Administration (CA) of the Assembly. Purposive sampling technique was used to select the DCD, DDCDs and the Sectional Heads of the Assembly because they are the pivot around which the HR capacity of the Assembly revolves. Quota sampling technique was used to allocate quotas for the other members of the Assembly depending on the various sections of the CA. In all, a total of 53 respondents made up of the DCD, the two DDCDs, nine Sectional Heads, 41 other members of the CA were involved in the study. Both primary and secondary data collection methods were used in gathering the relevant data for the study. Primary data were generated with the use of structured interviews and interview guide. The instruments sought to gather data on issues such as workers' views on the present institutional arrangements on the HR capacity, personnel capacity needs as well as the factors that influence the Assembly' HR capacity needs. 


\section{Results and Discussion}

The characteristics of respondents are discussed with respect to sex, age, academic qualification, and years of experience with the Assembly. The male respondents were $71.7 \%$ while the females were $28.3 \%$ as shown in Table 1 . This shows that the workforce at the CA of the Assembly was dominated by males. From public finance principle, the higher labor supply elasticities of women suggest that they should be taxed at lower rates than men (Blau \& Kahn, 2007).

Table 1. Sex distribution of the respondents at the assembly

\begin{tabular}{lll}
\hline Sex & Frequency & Percentage \\
\hline Males & 38 & 71.7 \\
Females & 15 & 28.3 \\
Total & 53 & 100 \\
\hline
\end{tabular}

Source: Field Survey, 2012

The prevailing situation at the Assembly raises issues of equity in the labor market as regards the employment situation of women since they must overcome historical disadvantages in an unfavorable economic environment. In a study conducted by the United Nations Economic Commission for Africa (2010), it was evident that the formal sector employment in Ghana where poverty is low is highly dominated by men. The Commission adds that gender dimension of poverty is likely to be biased against women if the situation in the formal sector continues in Ghana. The age distribution of the respondents showed that while $86.8 \%$ of the respondent had ages ranging from 20 to $49,13.2 \%$ had ages ranging from 50 to 59 as presented in Table 2. This implies that the Assembly had more youthful workers. This is an advantage the Assembly had given the retiring age in Ghana which is 60 years, thus that the ASDA had more workers not nearing retiring age. On the flip side, the Assembly could not be said to have more mature workers, who, if they had the requisite knowledge and skills coupled with positive work attitudes could contribute greatly towards the achievement of stated goals and objectives, and ultimately the development of the Assembly.

Table 2. Age distribution of respondents

\begin{tabular}{lcc}
\hline Age & Frequency & Percentage \\
\hline $20-29$ & 20 & 37.7 \\
$30-39$ & 11 & 20.8 \\
$40-49$ & 15 & 28.3 \\
$50-59$ & 7 & 13.2 \\
Total & 53 & 100 \\
\hline
\end{tabular}

Source: Field Survey, 2012

The Assembly had respondents of diverse academic qualifications, ranging from holders of Middle School Leavers Certificate (MSLC) to university degree. From Table 3 it is clear that $20.8 \%$ of the respondents of ASDA possessed MSLC, while $11.3 \%$ possessed university first degree. The Assembly did not have staff with the requisite skills. 
Table 3. Academic qualification of respondents

\begin{tabular}{lcc}
\hline Educational qualification & Frequency & Percentage \\
\hline MSLC/JHS & 11 & 20.8 \\
WASSCE/ SSSCE & 15 & 28.3 \\
Professional Certificate & 13 & 24.5 \\
HND/Diploma & 6 & 11.3 \\
$1^{\text {st }}$ Degree & 6 & 11.3 \\
$2^{\text {nd }}$ Degree & 2 & 3.8 \\
Total & 53 & 100 \\
\hline
\end{tabular}

Source: Field Survey, 2012

Out of the nine sectional heads of the Assembly, four possessed educational qualifications below Higher National Diploma (HND). Sensitive positions such as Sectional Heads may require qualifications that are higher than MSLC. Considering the onerous and sensitive duties bestowed on the DAs in Ghana, the qualifications of some of the Assembly staff seem inadequate in ensuring efficiency in performance for the attainment of the goals and objectives of the Assembly. This can hinder revenue generation since revenue collectors may lack the expertise in records keeping and basic accounting which could affect Assembly's revenue performance. This finding confirms that of Ndegwe and Levy (2003) and Gyabaah (2006) who found that most DAs in Ghana especially in the rural areas do not have personnel with the requisite qualifications and expertise to be able to deliver the expected functions of the assemblies. However, the obvious difficulty in appreciating Ndegwe and Levy's (2003) position is that most DAs in Ghana, especially in the rural areas, have poor social amenities which make it difficult for them to attract well-qualified personnel.

In addition to academic qualification and or professional training, one needs some level of experience to be competent in dealing with organizational and social issues. The respondents' total number of years spent with the Assembly ranged from below one year to 11 years as shown in Table 4. It is evident from Table 4 that majority $66 \%$ of the respondents of ASDA had working experience ranging from 3 to 11 years. This implies that most of the respondents of the Assin South District Assembly had the experience on the job to make them effective and efficient in their delivery. The finding contradicts that of Kokor (1991) who found that there exist limited experiences of local government personnel in Ghana.

Table 4. Years of experience with the assembly

\begin{tabular}{lcc}
\hline Years & Frequency & Percentage \\
\hline $0-2$ & 18 & 34.0 \\
$3-5$ & 18 & 34.0 \\
$6-8$ & 15 & 28.2 \\
$9-11$ & 2 & 3.8 \\
Total & 53 & 100 \\
\hline
\end{tabular}

Source: Field Survey, 2012

On the issue of institutional arrangements with respect to the HR capacities at the DAs, the study established that the existing institutional arrangements had had an impact on the Assembly's HR capacity. For instance, the evidence from the interview schedules indicated that the present institutional arrangements had negatively impacted on recruitment and selection (93.1\%), staff postings and transfers (90\%), staff motivation $(89.3 \%)$, staff promotion $(59 \%)$, training and development $(84 \%)$, retention of staff $(79.2 \%)$, staff replacement $(74.4 \%)$ at the Assembly as observed from Table 5. The respondents believed that the Assembly was not able to tackle its own HR needs because according to some of the key informants, there was poor collaboration between the local authorities and the central government. In the words of one of the key informants, "In many cases, instead of addressing their own HR needs, the Assembly was made to rely on the central government for solutions". Another key informant commented, "How can we be talking about effective decentralization when the central 
government is not ready to cooperate with the assemblies to address their human resource needs? They just do not want to cooperate in ensuring smooth decentralization".

Table 5. Views of sectional heads, DDCDs and other members of staff on the impact of institutional arrangements on the HR capacity at the assembly

\begin{tabular}{lccc}
\hline HR issue(s) & Satisfied & Dissatisfied & Undecided \\
\hline Recruitment and Selection & 5.6 & 93.1 & 1.3 \\
Staff Postings and Transfers & 6.5 & 90 & 3.5 \\
Staff Replacement & 12.6 & 74.4 & 13.0 \\
Training and Development & 10.4 & 84 & 5.6 \\
Staff Promotion & 29.7 & 59 & 1.3 \\
Staff Motivation & 6.7 & 89.3 & 4.0 \\
Staff Retention & 8.8 & 79.2 & 12.0 \\
\hline
\end{tabular}

Source: Field Survey, 2012

Another key informant retorted, "If the present arrangements is effective how come the Assembly is still plagued with inadequate HR capacity". On the whole, the influence of the Assembly in terms of HR issues was seen in times when the Assembly replaced workers who left the Assembly as a result of death, retirement or resignation. But this was found to be administratively very slow because the Assembly needed the approval of the central government. This situation contradicts the Civil Service Law (PNDCL 327) which guarantees the assemblies to take control of their own human resources to ensure smooth decentralization. This study supports Koranteng's (2006) assertion that the institutional arrangements are a problem to the HR capacity at the DAs. This means that there is more to the problem than the views expressed by Ahwoi (2010) which show that the issue has to do with poor image of the DAs and poor training and development at the DAs. Beyond this, Ayee, as cited in Tettey (2006), concedes that the current institutional arrangement makes the DAs unable to wield authority over their staff or elicit their full loyalty. This poses a huge challenge to the practical relevance of the principle of subsidiarity. The deficiency in the case of Ghana is evident given the situation in Tanzania where the LGs are given more freedom to adjust the staff to the local needs, hire, fire and discipline their staff, thus enhancing accountability (Steffensen et al., 2004).

Regarding the issue of personnel needs assessment at the Assembly, the study revealed that the ASDA did not conduct needs assessment at regularly which would certainly impede its HR capacity. In the words of key informant, "We don't pay much attention to needs assessment. I don't see why the Assembly should conduct needs assessment when it has virtually no role in terms of personnel management". On the quality of personnel at the Assembly, the majority (87.4\%) of the respondents believed that the Assembly did not have well qualified staff to achieve the goals of decentralization. Some of the respondents intimated that the inability to properly conduct needs assessment hampered the Assembly in terms of obtaining the required personnel to perform their expected functions. However, some of the key informants attributed the situation to the fact that they did not have autonomy over issues of personnel management. This revelation substantiates the views expressed by Water Aid Ghana (2009) that most of the DAs in Ghana do not conduct proper needs assessment.

Though the Assembly had an organogram of the District Administration, it did not indicate the number of staff needed by each section of the Assemblies. It was observed that the Assembly did not have adequate number of personnel. The sections in the Assembly had varying staff requirements and this is because they had diverse roles and expectations as presented in Table 6. In all, it can be observed from Table 6 that out of 102 required personnel, the Assembly had 57. Thus, the Assembly needed not less than 45 additional personnel in order to properly perform its entrusted functions. In the words of a key informant, "The Assembly does not have enough qualified staff for effective job performance. We need more qualified personnel. Sometimes we rely on consultants and other experts to handle some of the critical assignments". The Officer admitted that unlike other establishments, the DAs found it uneasy to attract well qualified personnel. This supports Antwi and Analoui's (2008) contention that most DAs lack adequate personnel to ensure smooth decentralization. Hoffman and Metzroth (2010) argue that factors such as poor social amenities especially in deprived areas hinder the DAs' ability to attract and retain well-qualified personnel for effective decentralization. Beyond this, the issue of the 
Assembly not having adequate qualified personnel is a challenge to the very existence and the practical intention of the human capital theory. This is because requisite HR is a critical requirement for organizational growth and sustainability (Haslinda, 2009). Ahwoi (2010) agrees with Koranteng (2006) that for the local governments to perform responsibilities devolved to them, there is the need for the DAs to have an appropriate human resource capacity. This will help them to better appreciate the demands of decentralization and the needs and preferences of the local people (Manor, 2011).

Table 6. The existing and required number of personnel at the assembly

\begin{tabular}{lccc}
\hline Section & Number at post & Total number required & Shortfall \\
\hline Administration \& Personnel & 14 & 21 & 7 \\
Finance & 6 & 12 & 6 \\
Environmental Health & 14 & 22 & 8 \\
Planning \& Budgeting & 3 & 6 & 3 \\
Internal Audit & 2 & 5 & 3 \\
Revenue & 12 & 18 & 6 \\
Security & 2 & 8 & 6 \\
Works & 4 & 10 & 6 \\
Total & 57 & 102 & 45 \\
\hline Source: Fi
\end{tabular}

Source: Field Survey, 2012

With regard to why the Assembly had not taken the initiative to employ workers to fill these vacancies, the study revealed that the Assembly did not have the mandate to do so. The key informants indicated that the Assembly only sent in applications for staff depending on the vacancies available, and after careful consideration, the OHSC, MLGRD or AG's Department would post personnel to the Assembly. They could only employ people to replace an employee who had left the Assembly, either by transfer, retirement or death upon the approval of OHCS, MLGRD or AG. In a study conducted by Green (2005) on East Asian decentralization, it was obvious that the implementation of devolved functions in Indonesia and the Philippines is running up against the limited staff capacities in local administration. Clearly, something has to be done about the present institutional arrangements so as to properly address the HR capacity needs at the Assembly for smooth local government system.

The study further examined the views of respondents on the factors hindering their performance. The results are presented in Table 7. It is clear from Table 7 that while some of the factors are common to the various sections of the Assembly, others were peculiar to each section of the Assembly. Logistics, such as computers, stationery, vehicles, security gadgets and sanitation equipment, were inadequate, according to the respondents. Logistics and infrastructure development are vital elements of capacity building, according to Dia (1996). Capacity building of staff at the LGS is critical for addressing the HR needs at the DAs. It is vital that efforts are made to deal with the various factors that hinder employee performance at the Assembly to ensure smooth decentralization (World Bank, 2003). Though they had informed management about the factors that inhibit their performance they had done virtually nothing about them. The implication may be a decline in the morale of staff, low performance by the staff and ultimately unattained goals and objectives. 
Table 7. Factors that hinder employee performance at the assembly

\begin{tabular}{lll}
\hline Section(s) & & \multicolumn{1}{c}{ Personnel capacity needs } \\
\hline $\begin{array}{l}\text { Administration \& \& } \\
\text { Office }\end{array}$ & Personnel & Computer, stationery, low motivation, insufficient office space \\
Audit & & low salaries, computer, poor incentives, inadequate personnel \\
Environmental health $\&$ Waste & Inadequate logistics, inadequate personnel, low motivation \\
Management & & Computer, poor incentives, inadequate personnel \\
Account/Finance & Computer \& accessories, inadequate personnel, low salaries, inadequate \\
Planning \& Budget & office space, poor remuneration \\
Revenue & Inadequate computer, stationery, poor remuneration, insufficient office \\
& space, inadequate training and development \\
Audit & Low salaries, computer, poor incentives, inadequate personnel \\
Security & Inadequate security gadgets such as torch lights, locks, low salaries, low \\
& motivation, inadequate personnel \\
Works & low salaries, poor remuneration, insufficient tools, inadequate personnel \\
\hline
\end{tabular}

Source: Field Survey, 2012

The key informants generally agreed that they did not have the financial capacity to properly address issues that hinder staff performance. They however admitted that it was crucial for the Assembly to put in place measures to bring about improved HR capacity and a well-motivated workforce to ensure successful decentralization. Antwi, Analoui and Cusworth (2007) argue that close working relationship with line and staff management and a track record of high quality services will go a long to revealing and understanding the variety of factors that hamper performance. If organizations fail to discover the factors that pose a difficulty to the successful execution of responsibilities then they will equally find it difficult to understand and appreciate the factors that are responsible for the attainment of their goals and aspirations (Noe, 2005).

With respect to issue of feedback, the study found that $64.1 \%$ of the respondents stated they got feedback on what was right or wrong with performance while $35.9 \%$ indicated that they did not get feedback on performance. What this means is that the staff of the Assembly did receive feedback on their performance. This is a strength which the Assembly should capitalize on to improve performance. However, the different views expressed by other members of staff indicate that there is still room for improvement. Performance standards are ineffective without constant measurement and feedback (McShane \& Von Glinow, 2000). McShane and Von Glinow (2000) add that for goal setting, feedback helps persons to know whether they have achieved the goal or are properly directing their effort toward it.

Regarding the factors that affect the HR capacity at the Assembly, the study revealed that poor recruitment process at the DAs played a role in the HR capacity needs at the DAs. A key informant stated, "The recruitment process at the DAs is fraught with many bottlenecks". Another key informant retorted, "There have been several occasions that the Assembly sent applications for personnel but those applications were never attended to leaving the Assembly with inadequate qualified personnel". They added that bureaucracies, corruption and nepotism derailed efforts to replace staff at the Assembly. The findings support Antwi and Analoui's (2008) assertion that corruption and bureaucracies contribute to the DAs' HR capacity needs. Ahwoi (2010) concedes that the issue of corruption appears to be a deep-seated canker within the District Assembly of Ghana.

It was also found that the majority (75.6\%) of the respondents stated that they never had any orientation and induction upon assumption of duty, while $24.4 \%$ stated they had. This means that the issue of workers not being given orientation and induction is a problem at the Assembly. Some of the key informants intimated that the Assembly did not have a structured orientation and induction program for the staff despite the importance of the program. Inadequate orientation program hinders the HR capacity of the DAs (MLGRD, 2007). Also, 83.9\% of the respondents stated that they were poorly motivated to work, while $16.1 \%$ indicated otherwise. When the respondents were further asked what would motivate them to stay on the job, they ranked wage or salary as the most important factor (89\%), followed by opportunity for career development (77\%), and inherent desire to help 
society as the last $(36.2 \%)$ as shown in Table 8 .

Table 8. Factors that would motivate the assembly's staff to stay

\begin{tabular}{lcc}
\hline Factors of motivation & Percentage & Rank \\
\hline Wage/Salary & 89.0 & 1 \\
Opportunity for career development & 77.0 & 2 \\
Fringe benefit and incentive & 72.3 & 3 \\
Occupational health and safety & 68.6 & 4 \\
Good human relations with superior & 63.6 & 5 \\
Inherent desire to help society & 36.2 & 6 \\
\hline
\end{tabular}

Source: Field Survey, 2012

The key informants commented that the Assembly did not have the financial capacity to properly deal with issues of staff motivation. They however admitted that the existing situation could lead to dissatisfaction among workers which could hamper effective job performance at the Assembly. This confirms the views expressed by Reiner (1957) that workers are basically motivated by economic factors that are in place. Economic factors including the level of pay and benefits, career development options are vital of worker performance. Donahue, Selden and Ingraham (2000) add that effective motivation at the DA level rests on the use of appropriate monetary and nonmonetary rewards and incentives, better performance appraisal system, and sound mechanisms that facilitate employee feedback. Beyond this, in Uganda, Francis and James (2003) established that the central government provides LGs with funds to address issues of staff remuneration and motivation. Antwi and Analoui (2008) bemoan that poor motivation at the DAs contributes to low staff satisfaction at the DAs which is a recipe for corruption within the assemblies in Ghana. The mode of promotion at the Assembly was also found to have an influence on the Assembly's HR needs as presented in Table 9. There were two categories of promotion lines in the Assembly namely, the management staff promotion line, and the non-management staff promotion line. The management workers were promoted through interview conducted at three-year intervals but the other workers were promoted through examination conducted by OHCS after every three-year interval.

Table 9. Views of the respondents on the mode of promotion in the assembly

\begin{tabular}{lcc}
\hline Mode & Freq. & Percent \\
\hline Well structured & 14 & 26.4 \\
Transparent & 5 & 9.4 \\
Not well structured & 3 & 5.7 \\
It delays & 31 & 58.5 \\
Total & 53 & 100 \\
\hline
\end{tabular}

Source: Field Survey, 2012

The management of the Assemblies only recommends staff for promotion. It was established that $58.5 \%$ of the respondents indicated that the mode of promotion delayed, while $26.4 \%$ were of the view that promotion was well structured as presented in Table 9. On the whole, the majority $(64.2 \%)$ of respondents were generally not satisfied with the mode of promotion at the Assembly. This could hamper the morale of workers at the Assembly. With respect to the relationship between staff and management at the Assembly, it was observed that the majority $(68.4 \%)$ of the respondents stated that there was a cordial relationship between staff and management while $31.6 \%$ management was not cordial. The DCD of the Assembly agreed that there was a cordial relationship between staff and management. What is vital is that there was a cordial relationship between most staff and management of the Assembly which, in the views of Noe (2005), ensures organizational effectiveness. Whether decentralization is a good idea from a theoretical point of view will depend upon the nature of the service and the capacity of personnel entrusted with the provision of service. The reality especially in most parts of Africa is that local governments are often at the mercy of local power elites, and this is an additional factor in evaluating the 
costs and benefits of decentralization in these settings. The human resource dimension ought to be properly addressed without any unnecessary interference from the central governments (Bardhan, 2002; Manor, 2011).

Regarding the issue of opportunity for training and development programs at the Assembly, it was observed that $64.5 \%$ of the respondents stated that there was unequal opportunity for training and development programs, while $35.5 \%$ disagreed. The key informants generally believed that opportunity for training and development at the Assembly was not equal. For instance, one of the key informants intimated, "Every year we expect that some training and development program will be organized for the staff of my section but this does not happen. When we ask them, they tell us that there is no money". Another key informant remarked, "There is no urgent effort to address the training needs of the staff". Jepppesen, as cited in Antwi and Analoui (2008) cautions that staff training and development must be viewed as an investment through a well-structured training and development with planning and budgeting similar to those dedicated to capital investments.

Despite the existing of training and development programs, the study revealed several areas that the workers of the Assembly needed training and development. They included basic knowledge in computer, the interpersonal skills in communication, organizational planning, budgeting and accounting principles, and performance appraisals (McShane \& Von Glinow, 2000). The emergence of the information age is characterized by the use of sophisticated technologies which enable the rapid transfer of information. A skilled and innovative workforce can be effective if workers are given training in information and communication technologies (Antwi, Analoui \& Cusworth, 2007; World Bank, 2003). It is common knowledge that the development of interpersonal skills is important for those employees who deal directly with the public. Faguet (2001) opined that decentralization could only be impactful if effective measures are put in place through enhanced public investment and proper capacity building.

On the issue of worker retention at the Assembly, the study revealed that $72.4 \%$ of respondents made up of the Sectional heads and the other members of the CA stated their desire to leave the Assembly. A number of factors such as low salaries, low remuneration, inadequate logistics, poor social amenities, and limited training and development opportunities accounted for their decision to leave the Assembly. Some of the respondents who had enrolled on distance education program pursuing Diploma in Basic Education from the University of Cape Coast conceded that if upon completion of their courses nothing changes in terms of the salary levels and remuneration at the Assembly, then they may be compelled to leave the place for other establishments. In the words of a respondent, "Am only waiting for the completion of my program to decide whether to stay here or leave". However, the respondents who had not made up their mind to leave the Assembly attributed it to the fact that they have few years to retire and would want to retire at the Assembly. The findings of the study lend credence to Reiner's (1957) position that one would opt for a job that offers a higher salary if the present job offers low salary. Antwi and Analoui (2008) also identify low salaries, poor staff satisfaction and limited training and development programs as factors inhibiting staff retention at the DAs. These views have also been supported by Ahwoi (2010) who argues that poor training and development and low job satisfaction impede the DAs' human resource capacity. Beyond this, Johnson (2001) pointed out that due to informational advantage based on a physical and institutional proximity to local residents, the devolution of political and administrative power to lower level governments leads to improved economic efficiency in local public service delivery and thus augments the growth rate at the national and regional levels. This can however be possible if the DAs have the requisite capacity to retain well-qualified personnel (Gyabaah, 2006; Johnson, 2001). In his study, Atakora (2006) observed that the rate of development in the Nkoranza District was low partly due to the fact that the Assembly did not have the requisite HR capacity to mobilize local revenue to undertake development projects in the district.

\section{Conclusions and Recommendations}

The study revealed that favorable institutional arrangements are a crucial factor in ensuring effective HR capacity at the decentralized government system. Despite its importance, the study results showed that the existing institutional arrangement regarding the HR capacity at the District Assemblies had contributed to the problematic HR capacity at the Assembly. A number of factors hindered staff performance at the Assembly. They included inadequate qualified personnel, poor remuneration, inadequate logistics, limited training and development programs, poor training facilities and low staff satisfaction. The strengths of the Assembly included the provision of feedback and the existence of cordial relationship among the employees. The study further showed that several factors influenced the HR capacity needs at the Assembly. They included low salaries, poor motivation, inadequate logistics, poor orientation and induction program, low staff satisfaction, and poor staff retention. The Assembly and the MLGRD had in place retention programs for their staff though there were conditions attached. On the issue of T\&D programs, the study showed that training programs at the Assembly 
were not based on proper needs assessment. Workers of the Assembly were, however, dissatisfied with how management had been responding to factors that hindered their performance. Unequal training and development opportunity at the Assembly had led the existence of training and development needs at the Assembly. However, it was observed that different sections of the Assembly had different training and development needs, with computer proficiency skills as the most commonly needed. Workers at the ASDA had thought of leaving the Assembly due to factors such as delay in promotion, inadequate orientation and low motivation derailed the Assembly's HR capacity needs. The study recommends that further research should be conducted into the cost involved in addressing the training and development needs at the District Assemblies in Ghana.

In order to ensure smooth decentralization, it is recommended that the MLGRD should decentralize its Human Resource Division to grant autonomy to the various Personnel Management Departments in the DAs to manage appointments and promotions in order minimize undue delays and travelling costs involved in the recruitment and promotion process in the Assembly. The MLGRD, Local Government Secretariat in conjunction with the Assembly should ensure that all the Sectional heads are persons who possess Degree in courses related to their job at the Assembly. The Assembly should also ensure flexible and attractive study leave packages to help develop the skills of personnel. The government should collaborate with the Assembly to conduct proper and regular needs assessment before addressing HR capacity needs. The Assembly must collaborate with the government and various NGOs within the district to address staff motivation, logistics, accommodation and entertainment allowance.

\section{References}

Ahwoi, K. (2006). Ghana's public administration reforms: Devolution, de-construction, delegation or decentralization? Journal of Leadership, Management and Administration, 4(2), 8-43.

Ahwoi, K. (2010). Local government and decentralization in Ghana. Accra: Unimax Macmillan.

and public investment in Bolivia. World Bank Working Paper Series 2516.

Antwi, K. B., \& Analoui, F. (2008). Challenges in building the capacity of human resource development in decentralized local governments: Evidence from Ghana. Management Research News, 31(7), 504-517. http://dx.doi.org/10.1108/01409170810876071

Atakora, A. N. (2006). Decentralization and effective revenue mobilization: A case study of the Nkoranza District Assembly. Journal of Leadership, Management and Administration, 4(2), 92-124.

Ayee, J. R. A. (1996). Governance and decentralization in Ghana: Retrospect and prospects. Accra: Anansesem Publication Ltd.

Bardhan, P. (2002). Decentralization of governance and development. Journal of Economic Perspectives, 16(4), 185-205. http://dx.doi.org/10.1257/089533002320951037

Blau, F., \& Kahn, L. (2007) .Changes in the labor supply behavior of married women: 1980-2000. Journal of Labor Economics, 25, 393-438. http://dx.doi.org/10.1086/513416

Central Regional Coordinating Council. (2009). Consultative process for the acceleration of decentralization in Ghana. Cape Coast: CRCC.

Crook, R. C., \& Sverrison, A. (2001). Decentralization and poverty alleviation in developing countries: A comparative analysis or is West Bengal unique? Brighton: Institute of Development Studies.

Dia, M. (1996). Africa's management in the 1990s and beyond: Reconciling indigenous and transported institution. Washington D.C.: World Bank. http://dx.doi.org/10.1596/0-8213-3431-X

Faguet, J. P. (2001). Does Decentralization increase government responsiveness to local needs? Decentralization

Francis, P., \& James, R. (2003). Balancing rural poverty reduction and citizen participation: The contradictions of Uganda's decentralization program. World Development. 31 (2), 325-337. http://dx.doi.org/10.1016/S0305-750X(02)00190-0

Gyabaah, N. K. (2006). Democratic decentralization, poverty reduction and sustainable development in Ghana: Challenges and opportunities. Journal of Leadership, Management and Administration, 4(2), 8-43.

Hoffman, B. D., \& Metzroth, M. K. (2010). The political economy of decentralization in Ghana. Center for Democracy and Civil Society, Georgetown University. Paper prepared for the World Bank

Johnson, C. (2001). Local democracy, democratic decentralization and rural development: Theories, challenges and options for policy. Development Policy Review, 19(4). http://dx.doi.org/10.1111/1467-7679.00149 
Jutting, J., Kauffmann, C., McDonnel, I., Osterrieder, H., Pinaud, N., \& Wegner, L. (2004). Decentralization and poverty in developing countries. Exploring the impact. OECD Development Centre Working Paper No. 236

Kokor, J.T. (1991). Local fiscal capacity for development: A comparative analysis of Ghana and Liberia. Dortmund: SPRING Centre, University of Dortmund.

Koranteng, R. O. (2006). The politics behind the decentralization policies in Ghana. Journal of Leadership, Management and Administration, 4(2), 8-43

Manor, J. (2011). Perspectives on decentralization. Visby: Swedish International Centre for Local Democracy.

Ministry of Local Government, \& Rural Development. (2007). Joint government of Ghana and development partner decentralization policy review report. Accra: MLGRD.

Mullins, L. J. (2007). Management and organizational behavior (8th ed.). Harlow: Pearson Education Ltd.

Ndegwa, S., \& Levy, B., (2003). The politics of decentralization in Africa: A comparative analysis. Washington DC: World Bank.

Noe, R. A. (2005). Employee training and development (3rd ed.). New York: McGraw-Hill.

Ribot, J. C. (2002). Democratic decentralization of natural resources: Institutionalizing popular participation. Washington, DC: World Resources Institute.

Ribot, J. C. (2004). Waiting for democracy: The politics of choice in natural resource decentralization. Washington, DC: World Research Institute.

Steffensen, J., Tidemand, P., \& Ssewankambo, E. (2004). A comparative analysis of decentralization in Kenya, Tanzania and Uganda. Country Report Uganda, August 2004, World Bank.

The Government of Ghana. (2010). National decentralization action plan: Accelerating decentralization and local governance for national development. Accra: MLGRD.

Water Aid Ghana. (2009). An assessment of local authorities donor fund management systems report. Accra: Water Aid Ghana.

Wood, S. N. (2000). Building the human resources capacity of district Assemblies. Koforidua: MLGRD.

World Bank. (1996). National capacity building assessment in Ghana. Washington, DC: World Bank.

World Bank. (2003). Human resource management. Washington, DC: World Bank.

\section{Copyrights}

Copyright for this article is retained by the author(s), with first publication rights granted to the journal.

This is an open-access article distributed under the terms and conditions of the Creative Commons Attribution license (http://creativecommons.org/licenses/by/3.0/). 